\title{
THE ROLE OF PHYSICAL EDUCATION IN IMPROVING THE HEALTH STATUS OF STUDENTS OF SPECIAL MEDICAL GROUPS
}

D0I: 10.36740/WLek202003125

\author{
Grygoriy P. Griban' ${ }^{1}$, Oleksii V. Tymoshenko², Valery G. Arefiev² ${ }^{2}$ Lyudmyla P. Sushchenko², Zhanna G. Domina², \\ Tetiana A. Malechko ${ }^{2}$, Iurii G. Zhuravlov ${ }^{3}$, Pavlo P. Tkachenk0 ${ }^{4}$, Andriy A. Baldetskiy ${ }^{5}$, Kostiantyn V. Prontenko ${ }^{6}$ \\ 'ZHYTOMYR IVAN FRANKO STATE UNIVERSITY, ZHYTOMYR, UKRAINE \\ NATIONAL PEDAGOGICAL DRAGOMANOV UNIVERSITY, KYIV, UKRAINE \\ ${ }^{3}$ NATIONAL UNIVERSITY «ZAPORIZHZHIA POLYTECHNIC», ZAPORIZHZHIA, UKRAINE \\ ${ }^{4}$ ZHYTOMYR NATIONAL AGROECOLOGICAL UNIVERSITY, ZHYTOMYR, UKRAINE \\ ${ }^{5}$ MILITARY INSTITUTE OF TARAS SHEVCHENKO NATIONAL UNIVERSITY, KYIV, UKRAINE \\ ${ }^{6}$ S. P. KOROLIOV ZHYTOMYR MILITARY INSTITUTE, ZHYTOMYR, UKRAINE
}

\begin{abstract}
The aim is to carry out the analysis of the disease incidence of students and to scientifically substantiate the directions of improving health and fitness activity in the physical education of the students of special medical groups.

Materials and methods: The study was conducted at Zhytomyr National Agroecological University in 1992-2019. The main pedagogical experiment involved 681 students (209 males and 472 females, aged 17-22). The research methods included theoretical methods (the analysis and synthesis of literary sources, the analysis of curricula, the assessment of the quality of classes with the students of special medical groups, the study and analysis of the medical cards of students); empirical methods (pedagogical observations, the methods of mathematical statistics).

Results: The study determined that more than $57.6 \%$ students of higher educational establishments of Ukraine had an unsatisfactory level of physical fitness, significant physical disabilities, diseases; from 10.9 to $20.5 \%$ students had an insufficient level of physical fitness and significant health disorders; from 8.1 to $17.4 \%$ students belonged to a special medical group; from 0.4 to $1.2 \%$ students were exempt from sports and had chronic diseases and disabilities.

Conclusions: The quality of the physical education process in special medical groups depends on the interconnection of all the components that affect its efficiency, including an outlook, motives, interests, the attitude of students to physical education and health-improving activities; the students' desire to overcome their health disabilities; individual characteristics of students; the means, forms, methods, and principles of physical self-improvement; material and technical support of educational and health and fitness events.
\end{abstract}

KEY WORDS: physical education, special medical group, disease incidence, physical fitness, students

Wiad Lek. 2020;73(3):534-540

\section{INTRODUCTION}

The main task of physical education classes in special medical groups is the elimination of residual after diseases, defects of the musculoskeletal system, functional abnormalities, deficiencies of physical development, and also the improvement of the level of physical fitness and necessary skills and abilities to use physical exercises for the health rehabilitation $[1,2,3]$. The students who belong to a special medical group train according to special programs that are developed by a teacher, and sometimes with the help of a doctor, taking into account the forms of diseases and the nature of physical abnormalities of particular students. Occasionally, the classes may be conducted according to the separate sections of the physical education program in a special training department, but with significantly reduced standards and extended deadlines. In some cases, therapeutic or corrective gymnastics classes may be held $[4,5,6]$.

At the same time, the system of the physical education of students who have chronic diseases, health problems, con- genital anomalies and the low levels of physical development and physical fitness, do not completely solves the problem of the restoration of working capacity and ensuring the normal functioning $[7,8,9,10,11]$. One of the causes of the disease incidence and health problems of students of Ukraine is the unsatisfactory condition of the physical education system at schools and higher educational establishments and its obsolescence $[12,13,14,15,16]$. If one summarizes the essence of the shortcomings in the system of physical education of the students of special medical groups, suggestions, and requirements of teachers regarding its reformation, it becomes clear that one can find the necessary ways to solve this problem by modernizing the system of physical education. The modernization of the system of physical education of the students of higher educational establishments of Ukraine, which the Ministry of Education and Science of Ukraine has been conducted recently, leads to the fact that physical education as a discipline loses its ability to solve simultaneously educational, pedagogical, and health-promoting problems that can provide a balanced pedagogical impact on 
Table I. The indicators of medical examination of the applicants and first-year students of Zhytomyr National Agroecological University in 1992-2019 (\%)

\begin{tabular}{|c|c|c|c|c|c|}
\hline \multirow{2}{*}{$\begin{array}{l}\text { The year of } \\
\text { examination }\end{array}$} & \multirow{2}{*}{$\begin{array}{c}\text { The number } \\
\text { of people }\end{array}$} & \multicolumn{3}{|c|}{ Medical groups } & \multirow{2}{*}{$\begin{array}{c}\text { With specia } \\
\text { needs }\end{array}$} \\
\hline & & The main group & The group with reduced activity & The special group & \\
\hline 1992 & 896 & 69.2 & 20.5 & 9.8 & 0.5 \\
\hline 1993 & 999 & 72.1 & 18.9 & 8.2 & 0.8 \\
\hline 1994 & 516 & 73.4 & 17.1 & 8.7 & 0.8 \\
\hline 1995 & 491 & 71.1 & 19.6 & 8.1 & 1.2 \\
\hline 1996 & 817 & 73.3 & 14.4 & 11.4 & 0.9 \\
\hline 1997 & 754 & 76.0 & 13.0 & 10.3 & 0.7 \\
\hline 1998 & 709 & 68.9 & 17.3 & 12.7 & 1.1 \\
\hline 1999 & 650 & 69.9 & 16.6 & 13.1 & 0.4 \\
\hline 2000 & 773 & 70.7 & 15.4 & 13.4 & 0.5 \\
\hline 2001 & 931 & 69.4 & 12.8 & 17.4 & 0.4 \\
\hline 2002 & 998 & 73.9 & 10.9 & 14.7 & 0.5 \\
\hline $2003^{*}$ & 1025 & 87.7 & - & 11.4 & 0.9 \\
\hline $2004^{*}$ & 1118 & 88.2 & - & 10.7 & 1.1 \\
\hline $2005^{*}$ & 1180 & 89.2 & - & 9.2 & 1.6 \\
\hline $2006^{*}$ & 1149 & 86.7 & - & 11.1 & 2.2 \\
\hline $2007^{*}$ & 1161 & 85.4 & - & 14.0 & 0.5 \\
\hline $2008^{*}$ & 1018 & 80.1 & - & 18.3 & 1.6 \\
\hline $2009^{*}$ & 1093 & 85.6 & - & 13.6 & 0.8 \\
\hline $2010^{*}$ & 1133 & 89.7 & - & 9.7 & 0.6 \\
\hline $2011^{*}$ & 875 & 87.5 & - & 11.9 & 0.6 \\
\hline $2012^{*}$ & 727 & 85.9 & - & 13.6 & 0.5 \\
\hline $2013^{*}$ & 658 & 76.7 & - & 22.9 & 0.4 \\
\hline $2014^{*}$ & 677 & 74.3 & - & 25.5 & 0.2 \\
\hline $2015^{*}$ & 567 & 78.6 & - & 21.2 & 0.2 \\
\hline $2016^{*}$ & 548 & 77.2 & - & 22.7 & 0.1 \\
\hline $2017^{*}$ & 698 & 69.0 & - & 30.4 & 0.6 \\
\hline $2018^{*}$ & 762 & 69.5 & - & 30.1 & 0.4 \\
\hline $2019^{*}$ & 724 & 55.1 & - & 44.1 & 0.8 \\
\hline
\end{tabular}

Note. From 2003 to 2019, the table presents data of the first-year students entered the university

a student, according to the requirements and possibilities of forming a creative, intellectual, morally stable and physically advanced personality $[3,11,17,18]$.

The physical education system existing at higher educational establishments of Ukraine cannot completely overcome the students' motor activity deficit; ensure efficient recovery, preservation, and improvement of the health of young students. The improvement of the efficiency of health promotion of the students of special medical groups can be achieved by reforming the methodical points of the physical education system, introducing a four-level model of health and fitness activities that includes a target component (the system of goals of the development of physical education and the formation of motives and interests in the activity); a content component (modern educational and methodical support); a procedural component (methods, forms, and means of training); a diagnostic and reflexive component (the control and evaluation of training efficiency).

\section{THE AIM}

The aim of the study is to carry out the analysis of the students' disease incidence and to substantiate scientifically the directions of improving health and fitness activity in the physical education of the students of special medical groups.

\section{The objectives:}

1) to conduct a systematic analysis of the physical condition and disease incidence of the applicants and students of higher educational establishments of Ukraine during a long historical stage;

2) to solve scientific and methodical problems of health and fitness activity in physical education, aimed at the elimination of residual after diseases, defects of the musculoskeletal system, functional abnormalities, and a low level of the physical development of the students of special medical groups. 
Table II. The structure of the disease incidence of the students of a special medical group ( $n=681,209$ males, 472 females; $\%$ of the total number of diseases)

\begin{tabular}{|c|c|c|c|c|c|c|}
\hline \multirow{2}{*}{ The classes of diseases } & \multirow{2}{*}{ Gender } & \multicolumn{4}{|c|}{ The year } & \multirow{2}{*}{ Totally } \\
\hline & & $1^{\text {st }}$ & $2^{\text {nd }}$ & $3^{\text {rd }}$ & $4^{\text {th }}$ & \\
\hline \multirow{2}{*}{$\begin{array}{l}\text { The diseases of the blood, blood- } \\
\text { forming organs, and circulatory system }\end{array}$} & males & 45.5 & 43.7 & 28.9 & 8.3 & 37.2 \\
\hline & females & 34.1 & 35.9 & 32.8 & 20.0 & 33.1 \\
\hline \multirow{2}{*}{$\begin{array}{l}\text { The diseases of the musculoskeletal } \\
\text { system }\end{array}$} & males & 10.6 & 18.3 & 14.5 & 16.7 & 14.5 \\
\hline & females & 17.4 & 11.6 & 8.6 & 11.1 & 12.5 \\
\hline \multirow{2}{*}{$\begin{array}{l}\text { The diseases of the urogenital and } \\
\text { endocrine systems }\end{array}$} & males & 12.1 & 10.9 & 14.5 & - & 12.1 \\
\hline & females & 11.6 & 9.2 & 12.9 & 22.3 & 12.1 \\
\hline \multirow{2}{*}{ The diseases of vision } & males & 4.5 & 3.6 & 6.6 & 25.0 & 6.3 \\
\hline & females & 8.7 & 10.4 & 4.3 & 4.4 & 7.8 \\
\hline \multirow{2}{*}{$\begin{array}{c}\text { The diseases of the gastrointestinal } \\
\text { tract }\end{array}$} & males & 4.6 & 1.8 & 9.2 & 8.3 & 5.8 \\
\hline & females & 2.9 & 7.5 & 10.4 & 17.8 & 7.8 \\
\hline \multirow{2}{*}{$\begin{array}{l}\text { The diseases of the respiratory system } \\
\text { and organs }\end{array}$} & males & 1.5 & 3.6 & 9.2 & 16.7 & 4.8 \\
\hline & females & 5.1 & 6.9 & 9.5 & 2.2 & 6.6 \\
\hline \multirow{2}{*}{$\begin{array}{l}\text { The diseases of the nervous system and } \\
\text { sense organs }\end{array}$} & males & 6.1 & 3.6 & 2.6 & 16.7 & 4.8 \\
\hline & females & 8.7 & 4.0 & 7.7 & 4.4 & 6.4 \\
\hline \multirow{2}{*}{ Congenital anomalies } & males & 4.5 & - & 1.3 & - & 1.9 \\
\hline & females & 0.7 & 0.6 & - & - & 0.4 \\
\hline \multirow{2}{*}{ Others } & males & 10.6 & 14.5 & 13.2 & 8.3 & 12.6 \\
\hline & females & 10.8 & 13.9 & 13.8 & 17.8 & 13.3 \\
\hline \multirow{2}{*}{ Totally } & males & 32.4 & 24.1 & 39.6 & 21.1 & 30.7 \\
\hline & females & 67.6 & 75.9 & 60.4 & 78.9 & 69.3 \\
\hline
\end{tabular}

Note. The structure of the diseases is based on the diseases, according to which the students belong to a special medical group

\section{MATERIALS AND METHODS}

The research was conducted at Zhytomyr National Agroecological University. It involved the students of the Faculty of Veterinary Medicine, Ecology and Law, Engineering and Energetics, Forestry, Economics and Management, Accounting and Finance, Technological and Agronomy. The examination of applicants concerning the health status and physical fitness was conducted in 1992-2002. The evaluation of the disease incidence rate of first-year students was carried out from 2002 to 2019 , according to the results of medical examinations using medical cards and doctors' conclusions. The medical examinations were conducted by doctors at the university's medical center and the municipal polyclinic. The main pedagogical experiment involved 681 students (209 males and 472 females, aged 17-22). The analysis, systematization, and generalization of the literary sources and medical records of students allowed us to form the general situation of the disease incidence of the students of the university and Ukrainian higher educational establishments. In the second stage of the study, a comparative analysis of the students' diseases was carried out and they were classified. At the final stage of the research (2019), the final analysis and interpretation of the obtained scientific data were made.

The research methods included theoretical methods (the analysis and synthesis of literary sources, the analysis of curricula, methodical support, and the quality of classes with the students of special medical groups, the study and analysis of the medical cards of students); empirical methods (pedagogical observations, the methods of mathematical statistics).

This study complies with the ethical standards of the Act of Ukraine "On Higher Education" No.1556-VII dated 01.07.2014 and the Letter from the Ministry of Education and Science of Ukraine "On the Academic Plagiarism Prevention" No. 1/11-8681 dated 15.08.2018. Also, this study followed the regulations of the World Medical Association Declaration of Helsinki - ethical principles for medical research involving human subjects. Informed consent was received from all individuals who took part in this research.

\section{RESULTS}

The level of the health status of students depends significantly on the state of physical culture in the family and at the school, on following a healthy lifestyle, using the means of preventing diseases by young students that is the initial level of the health state of an applicant to a higher educational establishments. There has been a significant decline in health and in the level of physical fitness of students. The examination of the physical development and physical fitness of the applicants and firstyear students of Zhytomyr National Agroecological University 
during many years showed that more than $57.6 \%$ of them had unsatisfactory physical fitness, significant physical disabilities, diseases; from 10.9 to $20.5 \%$ students had an insufficient level of physical fitness, significant health disorders and they belonged to a group with reduced activity; from 8.1 to $17.4 \%$ students belonged to a special medical group; from 0.4 to 1.2 $\%$ students were exempt from sports and had chronic diseases and disabilities (Table I).

The analysis of diseases, data of the physical development and physical fitness of applicants showed that from 24.0 to $30.8 \%$ of them had diseases, including chronic, congenital anomalies, disability, very bad physical development (postural disorders, overweight and underweight, disproportionate physical development, problems with the functional abilities of an organism, etc.). When performing physical education tests and physical development assessments, a large number of applicants did not have the technical skills and knowledge about the necessity of such evaluations and of the performance of tests. In addition, a scientific analysis of the medical examination of school-age children conducted in Zhytomyr Region during fifteen years showed that the level of sick children ranged from 40.9 to $69.2 \%$ $[4,19]$. Accordingly, the low indicators of the health status and physical fitness of students are not accidental because university applicants are school graduates.

The analysis of medical examinations of first-year students carried out in 2003-2019 indicates negative tendencies in the health status of young people entering the universities of Ukraine. The main group included 74.3-89.7 \% students, the special medical group involved 9.2-25.5\% students; from 0.1 to $2.2 \%$ students had significant abnormalities in health status, chronic diseases, disorders of the musculoskeletal, cardiovascular, respiratory, nervous, endocrine systems, etc.

In 2017-2019, the Ministry of Education and Science of Ukraine modernized the system of physical education of university students, trying to bring it closer to the European level. First, the Departments of Physical Education were closed and the discipline of Physical Education was turned into an optional and independent form of study. At the same time, the material and technical support of Ukrainian universities is ten times inferior to the European universities, the mentality of Ukrainian students is such that they are not used to independent exercise, and there are no specialists in Ukraine who could quickly introduce modern European fitness technologies into the physical education process. All this began to destroy the Ukrainian system of physical education in higher educational establishments. Our research showed that the number of students who belonged to the special medical group was increased to $30.4 \%$ in 2017 , to $30.1 \%$ in 2018 , and the elimination of medical centers and polyclinics at universities and the lack of proper medical care for students led to an increase in the number of students in a special medical group to $44.1 \%$ in 2019 . This situation significantly worsened the quality of students' education, their level of physical fitness and working capacity.

Since 2009, 30.7\% male and 69.3\% female students belonged to a special medical group. A similar situation has survived to this day. There was also a clear tendency that a special medical group included more females than males. Regarding the structure of student disease incidence, it has significant differences among the authors $[1,5,20,21]$. One of the reasons is the wrong approach to studying the structure of diseases. The students of the special education group most often have the diseases of the blood, blood-forming organs, circulatory system, musculoskeletal system (apparatus system and conjunctive tissue), urogenital and endocrine systems, vision, gastrointestinal tract, respiratory organs, organs of senses, nervous system, etc. Among the diseases of the respiratory organs, the most common are chronic bronchitis, pneumonia, bronchial asthma. Among the total number of diseases, cardiovascular diseases account for $37.2 \%$ for males and $33.1 \%$ for females; the diseases of musculoskeletal system account for $14.5 \%$ for males and $12.5 \%$ for females; urogenital and endocrine systems - 12.1 $\%$ for males and $12.1 \%$ for females (Table II). Such diseases require the use of special health-improving physical exercises of a dynamic and cyclic nature. Physical activity should cause a small and moderate physiological response. To unload the cardiovascular system, it is possible to make exercises in a sitting position, lying, reclining, exercises with the raised legs.

The structure of the students' disease incidence is not actually changed during the period of study at higher educational establishments that is also confirmed by the data of other scientists [2]. The overall dynamics of the disease incidence of both males and females have some peculiarities. The disease incidence of males was decreased from 32.4 to $24.1 \%$ in the second year, and on the contrary, the females' was increased from 67.6 to $75.9 \%$ (Table III). There were also differences defined in the dynamics of the diseases of the students from different regions and higher educational institutions between the students of the $3 \mathrm{rd}$ and the 4 th years [10].

The wide range of diseases and their quantitative and qualitative features require the departments of physical education to develop new methods of physical education, based on the principle of adequate physical activity, which corresponds to the level of health, characteristics of the disease and the interests of the students of special medical groups in different educational establishments. Therefore, we cannot but agree with scientists $[18,22]$ that the program strategy of the physical education of students should be based on a new paradigm of health, enriched with basic knowledge in the field of biology and health physiology, sport physiology, on the establishment of cause and effect dependencies between ordinary physical activity, mental capacity, and health, taking into account the psychological characteristics of the student's personality. And a student's organism, including all its components, such as physical, intellectual, moral, emotional, social, undergoes development and formation.

Accordingly, the methodical support of the health and fitness activity of the students of a special medical group should differ from the methodical system of the classes of the students of the main educational department not only in the amount of physical activity but qualitatively another physical activity. One of the quite efficient means of improving the quality of the educational process in a special medical group is the establishment of a clear system of assessment of students, the determination of criteria for exams in physical education. At the same time, the system of assessment must be humane, discrimination against an individual, limitation of one's dignity because of the different 
Table III. The dynamics of the disease incidence of students during studying at higher educational establishments ( $n=681,209$ males, 472 females; $\%$ of the total number of diseases)

\begin{tabular}{cccccc}
\hline \multirow{2}{*}{ Gender } & \multicolumn{4}{c}{ The years of studying } \\
\cline { 2 - 6 } & $\mathbf{1}^{\text {st }}$ & $\mathbf{2}^{\text {nd }}$ & $\mathbf{3}^{\text {rd }}$ & $\mathbf{4}^{\text {th }}$ & 21.1 \\
\hline Males & 32.4 & 24.1 & 39.6 & 60.4 & 78.9 \\
\hline Females & 67.6 & 75.9 & & 78.9 \\
\hline
\end{tabular}

Table IV. Control tests and standards of assessment of the physical fitness of the students of a special medical group (males)

\begin{tabular}{|c|c|c|c|c|c|}
\hline \multirow[t]{2}{*}{ Tests } & \multicolumn{5}{|c|}{$\begin{array}{l}\text { The criteria for assessing the improvement of the physical fitness indicators } \\
\text { (the requirements and points) }\end{array}$} \\
\hline & 5 & 4 & 3 & 2 & 1 \\
\hline $3000 \mathrm{~m}$ race, $\mathrm{min}, \mathrm{s}$ & -2.30 & -1.55 & -1.20 & -0.40 & e. I.* \\
\hline $100 \mathrm{~m}, \mathrm{~s}$ & -1.4 & -1.0 & -0.6 & -0.3 & e. I.* \\
\hline Standing long jumps, sm & +35 & +25 & +15 & +10 & e. I.* \\
\hline Push-ups, reps & +10 & +8 & +6 & +4 & e. I.* \\
\hline Pull-ups, reps & +10 & +7 & +4 & +2 & e. I.* \\
\hline Sit-ups, reps & +16 & +13 & +9 & +6 & e. I.* \\
\hline $4 \times 9 \mathrm{~m}$ shuttle running, $\mathrm{s}$ & -1.2 & -0.9 & -0.6 & -0.3 & e. I.* \\
\hline Forward reach from a sitting position, sm & +12 & +10 & +7 & +3 & e. I.* \\
\hline
\end{tabular}

Note. e. l.* - an entry level (initial datum is individual for every student)

levels of physical abilities are unacceptable. A teacher should be focused not on the results in the tests of physical fitness but the students' attitude to this type of activity, the level of motivation, the need for physical exercises after passing an exam, during vacations, after graduation.

At the same time, the standards in the educational process are necessary as a social norm of the physical fitness of students and the basis of the formation of the whole system of physical education. Otherwise, the physical education process will not be focused on health but may be reduced just to entertainment or outside activities. In order to enhance the attitude of students with disabilities and health defects to the process of physical education, we also developed and implemented control tests and standards for assessing physical fitness in a special medical group (Tables IV, V).

The standards are not a dogma for students but only a guide and an incentive to improve their initial level of physical fitness. The suggested system of physical fitness assessment requires the development of the scientific and methodological support of a new generation for the departments of physical education, more qualitative preparation of teachers for the work with students of special medical groups, the determination of special forms and the content of independent work and efficient means of monitoring the health of such students.

The other form of recovery activation and preservation of the health of the students of special medical groups is the systematic educational and practical work of a student with monitoring of the problems caused by one's disease by a teacher. In this case, a student learns the history of one's disease, the ways to behave in everyday life concerning the disease, dietary regime, the methods of treatment and organism recovery (pedagogical, psychological, hygienic, medical and biological, folk, etc.), forms the regime of motor activity, mentioning specific exercises, which one performs systematically at home, morning exercises, the complexes of exercises for physical activity breaks while doing homework. This is one of the tasks for passing an exam or a positive certification.

\section{DISCUSSION}

Our study reveals the reasons for the disease incidence and low physical fitness of the students of special medical groups, the analysis, and the classification of diseases. It is revealed that the main cause of a large number of diseases is the low level of motor activity of students, the physical condition and disease incidence of university applicants.

The following requirements must be considered for the development of the physical qualities of the students of special medical groups:

- to develop physical qualities only after reaching a sufficient level of functioning of the basic systems of an organism (respiratory, cardiovascular, nervous, etc.);

- to follow the sequence of the development of physical qualities: endurance, strength, speed. Flexibility and coordination skills can be developed from the first classes, taking into account the contraindications of individual students;

- to use moderate power exercises and physical activity, not to force the development of endurance when a student has an unsatisfactory state of the musculoskeletal system, excess body weight, obesity or abnormalities of the central and peripheral nervous system;

- during the development of power, maximum physical loads are not allowed. It is better to increase the number of repetitions of moderate exercise, to focus on the development of endurance; - during the development of speed, special attention should be paid to the abnormalities of the musculoskeletal, nervous 
Table V. Control tests and standards of assessment of the physical fitness of the students of a special medical group (females)

\begin{tabular}{|c|c|c|c|c|c|}
\hline \multirow[t]{2}{*}{ Tests } & \multicolumn{5}{|c|}{$\begin{array}{l}\text { The criteria for assessing the improvement of the physical fitness indicators } \\
\text { (the requirements and points) }\end{array}$} \\
\hline & 5 & 4 & 3 & 2 & 1 \\
\hline $2000 \mathrm{~m}$ race, $\min , \mathrm{s}$ & -2.00 & -1.25 & -1.00 & -0.25 & e. l.* \\
\hline $100 \mathrm{~m}, \mathrm{~s}$ & $-2,3$ & $-2,0$ & $-1,7$ & $-0,8$ & e. I.* \\
\hline Standing long jumps, sm & +40 & +30 & +20 & +10 & e. I.* \\
\hline Push-ups, reps & +8 & +6 & +4 & +2 & e. I.* \\
\hline Hanging on the crossbar with bent arms, s & +11 & +9 & +6 & +3 & e. l.* \\
\hline Sit-ups, reps & +15 & +11 & +7 & +4 & e. I.* \\
\hline $4 \times 9 \mathrm{~m}$ shuttle running, $\mathrm{s}$ & $-1,5$ & $-1,1$ & $-0,7$ & $-0,2$ & e. I.* \\
\hline Forward reach from a sitting position, sm & +14 & +11 & +8 & +5 & e. I.* \\
\hline
\end{tabular}

Note. e. I. ${ }^{*}$ an entry level (initial datum is individual for every student)

and cardiovascular systems; to have a proper warm-up before performing the speed exercises;

- to combine physical exercises with respiration ones; to apply exercises with an optional duration of the respiratory cycle, aimed at improving the drainage function of the respiratory tract;

- to perform relaxation exercises, aimed at relaxing the muscles, alternating and combining tension and relaxation for the purpose of health-improving and recovery of the organism's functions after diseases.

It should be noted that only the organization of physical education, which engages both teachers and students in the management of the educational process, promotes the increased physical activity of students, deprives them of homogeneous traditional regulation. This makes it possible to change the position of students in the educational process, that is, to ensure that they become not only the object of the teachers' influence but also the subjects of their own activity, the equal participants in the management of the educational process. The initiatives make students individually and collectively responsible for the results of classes, sports and health-promoting events. The freedom of choice, variety of classes, maximum autonomy in decision-making, the desire to make their activities useful for themselves and the society are the vital conditions for the formation of the physical activity of the students of special medical groups.

The results of our studies confirm and supplement the conclusions of many scientists $[1,8,10,13,15,23,24,25]$.

\section{CONCLUSIONS}

1. The analyses and assessment of the state of students' disease incidence during the study at a higher educational establishments require the development of a modern scientific and methodical support for the process of physical education for the students of special medical groups, determining the special form and content of independent work and efficient means of controlling their health. Understanding the priority of the problem of the implementation of health-saving technologies in the educational process is crucial for the formation of the educational environment which will improve the students' health.
2. In order to activate the educational process and health and fitness activities of the students of special medical groups, it is necessary to interconnect all the components that may affect their quality and efficiency, namely: 1) to study an outlook, motives, interests, the attitude of students to physical education and health-improving activities; 2) to define the students' desire to overcome their health disabilities; 3 ) to identify individual characteristics of students, their level of knowledge about the causes of diseases and the physical development delay; 4) to substantiate the means, forms, methods, and principles of physical self-improvement; 5) to provide the maximum level of material and technical support of educational and health and fitness events for the students of special medical groups concerning their diseases and health abnormalities.

The prospects for further research are aimed at exploring the peculiarities of applying the means of physical health and fitness activities by the students with a low health level.

\section{REFERENCES}

1. PrysiazhniukS., Tolubko V., Oleniev D. et al. The influence of physical activities on biological age parameters of the first-year female students from the special medical department. Journal of Physical Education and Sport.2018; 18(2):561564. doi:10.7752/jpes.2018.02081.

2. Bodnar I. P., Stefanyshyn M. V., Petryshyn Y. V. Assessment of senior pupils' physical fitness considering physical condition indicators. Pedagogics, Psychology,Medical-biological Problems of Physical Training and Sports, 2016; 6:9-17. doi:10.15561/18189172.2016.0602.

3. Krutsevych T. Yu. Teoriia i metodyka fizychnoho vykhovannia [Theory and methods of physical education]: pidruchnykdlia stud. vuzivfiz. vykhov. isportu. T. 1.Zahalni osnovy teorii i metodyky fizychnoho vykhovannia. Kyiv: Olympic Literature; 2008, 391 p. (In Ukrainian).

4. Griban G.P.Tkachenko P.P.,DzenzelyukD.0. etal.Udoskonalennya organizatsiyi i provedennya navchalnih zanyat zi studentami spetsialnoyi medichnoyi grupi [Improvement of organization and conducting of training sessions with students of special medical group].Problemisuchasnoyivaleologiyi, fizichnoyi kulturi ta reabilitatsiyi. 2011; 1:97-101. (In Ukrainian).

5. Malimon 0., Volchinskiy A. Dinamika zahvoryuvanosti ta stanu zdorov'ya studentiv [Dynamics of student morbidity and health]. Fizichne vihovannya, sport i kultura zdorov'ya u suchasnomu suspilstvi. 2005; 1: 286-289. (In Ukrainian). 
6. Apanasenko G., Dolzhenko L. Rivenj zdorov'ja i fiziologhichni rezervy orghanizmu. [The level of health and physiological reserves of the organism]. Teorija i metodyka fizychnogho vykhovannja i sportu. 2007; 1: 17-21. (In Ukrainian).

7. Prontenko K., Griban G., Aloshyna A. et al. The physical development and functional state as the important components of the students' health. Wiad. Lek. 2019; 72 (12a) : 2348-2353. doi: 10.36740/WLek201912115.

8. Gruzieva T., Galiienko L., Pelo I. et al. Health and lifestyle of students' youth: status, problems and ways of solution. Wiad Lek. 2018;71(9):1753-1758.

9. Prontenko K., Griban G., Dovgan N., et al. Students' health and its interrelation with physical fitness level. Sport Mont. 2019; 17(3): 41-46. doi 10.26773/ smj.191018.

10. Mozolev 0., Halus 0., Bloshchynskyi l. et al. Human resources management of educational development in sphere of physical culture and sports in Ukraine: comparative analysis (1992-2016). Journal of Physical Education and Sport. 2019; 19(Supplement issue 1): 185-192. doi:10.7752/jpes.2019.s1028.

11. Griban G. P. Zhyttiediialnist ta rukhova aktyvnist studentiv [Life activity and mobility of students]. Zhytomyr: Ruta; 2009, 594 p. (In Ukrainian).

12. Futornyj S. M. Dvyghateljnaja aktyvnostj y ee vlyjanye na zdorovj'e y prodolzhyteljnostj zhyzny cheloveka [Motor activity and its effect on human health and longevity]. Fyzycheskoe vospytanye studentov. 2011; 4: 79-84. (In Russian).

13. Bolotin A., Bakayev V. Structure and content of the educational technology of managing students' healthy lifestyle. Journal of Physical Education and Sport. 2015; 15(3):362-364. doi:10.7752/jpes.2015.03054.

14. Muntjan V. S. Analyz faktorov, opredeljajushhykh zdorovje cheloveka y okazyvajushhykhnaneghovlyjanyja [Analysis offactors that determine human health and influence it]. Fyzycheskoe vospytanye studentov. 2010; 6: 44-47. (In Russian).

15. Kharchenko 0., Kharchenko N., Shaparenko I. et al. Analysis of the physical development ofyouthand thestate ofits health.Wiad Lek. 2019;72(4):575-578.

16. Mozolev 0., Khmara M., Shorobura I. et al. Comparative Analysis of the effectiveness of Polish and Ukrainian basic training programs in physical education for 9-10-year-old pupils. Universal Journal of Educational Research. 2019; 7(11):2345-2351. doi: 10.13189/ujer.2019.071112.

17. Prontenko K., Bloshchynskyi I., Griban, G. et al. Formation of readiness of future physical culture teachers for professional activity. Universal Journal of Educational Research.2019;7(9): 1860-1868.doi: 10.13189/ujer.2019.070903.

18. Semeniv B., Babych A., Bilenjkyj P. et al. Educational model of physical training of students of bio-technological profiles. Physical Education, Sports and Health Culture in Modern Society, 2018; 1(41): 52-60. doi:https://doi. org/10.29038/2220-7481-2018-01-52-60.

19. Griban G., Prontenko K., Zhamardiy V. et al. Professional stages of a physical education teacher as determined using fitness technologies. Journal of Physical Education and Sport. 2018; 18(2): 565-569. doi:10.7752/jpes.2018.02082.

20. Mozolev 0., Bloshchynsky I., Alieksieiev 0. et al. Influence of modern fitness technologies on the state of health and development of motor abilities of 17-19-year-old female students. Journal of Physical Education and Sport. 2019; 19(Supplement issue 3): 917-924. doi:10.7752/jpes.2019.s3132.

21. Prontenko K., Griban G., Prontenko V. et al. Health improvement of cadets from higher military educational institutions during kettlebell lifting activities. Journal of Physical Education and Sport. 2018; 18(1): 298-303. doi:10.7752/ jpes.2018.01040.
22. Maghljovanyj A. V. Osnovy informacijnogho polja zdorov'ja osobystosti [Basics of information field of personality health]. Visnyk Chernighivsjkogho nacionaljnogho pedaghoghichnogho universytetu imeni T. Gh. Shevchenka. Serija: Pedaghoghichni nauky. Fizychne vykhovannja ta sport. 2010; 81: 285289. (In Ukrainian).

23. Warburton D.,NicolC.W., Bredin S. S. D. Health benefits of physical activity: the evidence. Canadian Medical Association Journal. 2006; 174: 801-809.

24. Mandic S., Wilson H., Clark-Grill M., O’Neill D. A. Physical activity learning module improves medical students'skills and confidence for advising patients about physical activity. Monten.J.Sports Sci. Med., 2018;7(2018)1:31-38. doi 10.26773/mjssm.180304.

25. Stachon A., Pietraszewska J., BurdukiewiczA., Andrzejewska J.The differences in fat accumulation and distribution in female students according to their level of activity. Human Movement, 2016; 17(2):87-93. doi: 10.1515/humo-20160009.

The work was carried out according to the plan of the Ministry of Agrarian Policy and Food of Ukraine on the theme of "Theoretical and methodological bases of the optimization of the physicaleducation system of the students of the Ukrainian higher educational institutions" (state registration number 0112U001618).

\section{ORCID and contributionship:}

Grygoriy P. Griban - 0000-0002-9049-1485 A, E

Oleksii V. Tymoshenko - 0000-0002-5310-4941 A, B

Valery G. Arefiev - 0000-0001-9789-9611 D

Lyudmyla P. Sushchenko - 0000-0002-2461-3739 C

Zhanna G. Domina - 0000-0002-8315-6590 ${ }^{D}$

Tetiana A. Malechko - 0000-0001-9430-6745 ${ }^{\mathrm{F}}$

Iurii G. Zhuravlov - 0000-0001-7342-1031 ${ }^{\mathrm{C}}$

Pavlo P. Tkachenko - 0000-0003-4407-8611 ${ }^{\mathrm{E}}$

Andriy A. Baldetskiy - 0000-0001-6979-066X ${ }^{B}$

Kostiantyn V. Prontenko - 0000-0002-0588-8753 E,F

\section{Conflict of Interest.}

The Authors declare no conflict of interest.

\section{CORRESPONDING AUTHOR Kostiantyn V. Prontenko}

S. P. Koroliov Zhytomyr Military Institute, Zhytomyr, Ukraine tel: +380675069142

e-mail: prontenko-kostya@ukr.net

Received: 17.01 .2020

Accepted: 05.03 .2020

A - Work concept and design, B - Data collection and analysis, C - Responsibility for statistical analysis, D-Writing the article, $\mathbf{E}$-Critical review, $\mathbf{F}$ - Final approval of the article 